\author{
Marta RYMAR ${ }^{1}$ \\ Lucjan ŚLECCZKA ${ }^{2}$
}

\title{
RESISTANCE AND DURABILITY ANALYSIS OF STEEL SUPPORTING STRUCTURE ON THE BELL TOWER OF ST. TRINITY CHURCH IN KROSNO
}

\begin{abstract}
The paper describes the analysis of steel structure, supporting three bells in the belfry of St. Trinity Church in Krosno. The structure is dated from 1928 and has a form of riveted space truss, with slender members. The total mass of all bells, coming from the 17 th century, is nearly equal to 4200 kilograms, so the dynamic forces coming from bells swinging are quite large. The paper describes specific problems associated with assessing the resistance of old steel structure, treated as a relic. The analysis covered technical condition assessment of the structure, evaluation of actions and environmental influences, mechanical parameters prediction of steel and rivets by non-destructive methods and also static and dynamic analysis of the structure. According to many years of exploitation, the fatigue verifications were also performed using the classification method.
\end{abstract}

Keywords: bell tower, static analysis, dynamic analysis, fatigue

\section{Introduction}

Krosno is a town situated in the south of the Podkarpackie Province. It is famous from many relics, monuments and old buildings. One of them is the bell tower of St. Trinity church, containing bells dating from the 17th century. There are three bells housed in the belfry, called Urban, Maryan and Jan. The largest one is Urban, with diameter equal to $1535 \mathrm{~mm}$. It has about 2400 kilograms in weight and is commonly considered as one of the largest historical bells in Poland. The total mass of all three bells is close to 4200 kilograms, so the dynamic actions produced by swinging have a great effect on the supporting structure and on the tower. Steel structure directly supporting the bells

\footnotetext{
${ }^{1}$ Marta Rymar, Historic Preservation Officer in Krosno, ul. Staszica 2, 38-400 Krosno, tel. 1347436 31, rymar.marta@um.krosno.pl

${ }^{2}$ Author for correspondence: Lucjan Ślęczka, Politechnika Rzeszowska, Katedra Konstrukcji Budowlanych, ul. Poznańska 2, 35-084 Rzeszów, sleczka@prz.edu.pl
} 
in the bell chamber is dated from 1928 and has a form of riveted space truss. Recently, the interior of the belfry became publicly available. According to the safety reasons, the supporting steel structure was analyzed to assess its strength and durability.

\section{Cultural and historical background}

The bell tower of St. Trinity Church in Krosno was built between 1637 and 1651. It was founded by Robert Wojciech Portius (Gilbert Porteous Lanxeth), citizen of Krosno from 1621, native of Scotland. The main body of tower has a nearly square section. Its width is about $8,8 \div 9,0$ (Fig. 1 and 2). The main body is made of masonry. The thickness of the walls is $2,2 \mathrm{~m}$ at the wall basement and $1,25 \mathrm{~m}$ at the level of the bells' chamber $(+9,54)$. The tower crown has a timber structure. The total height of the tower is $38,0 \mathrm{~m}$. One wall of the tower is connected with the presbytery.

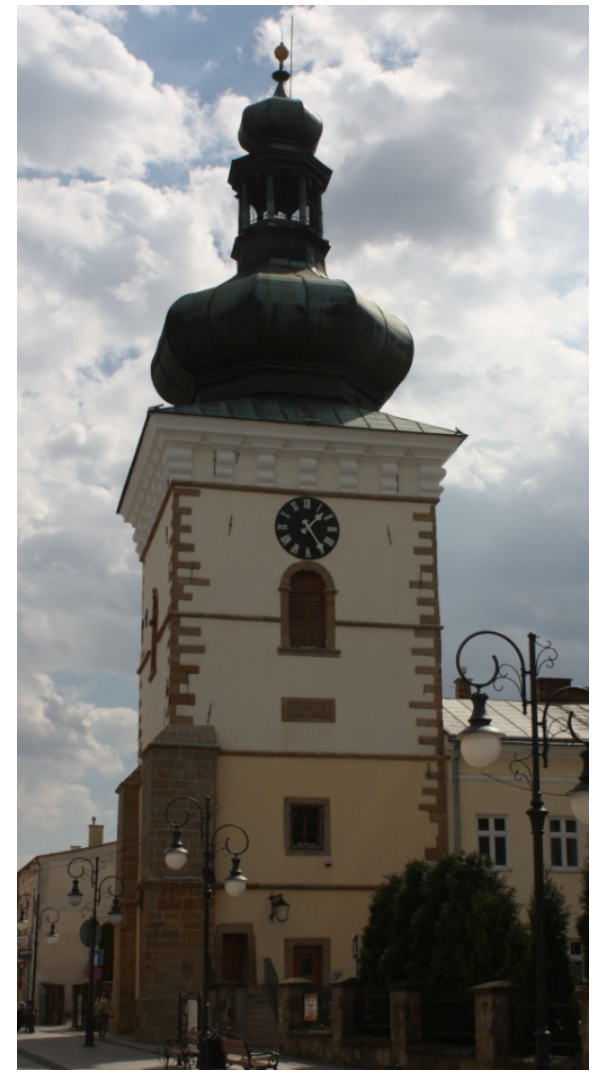

Fig. 1. North façade of the bell tower Rys. 1 Północna fasada wieży dzwonnicy

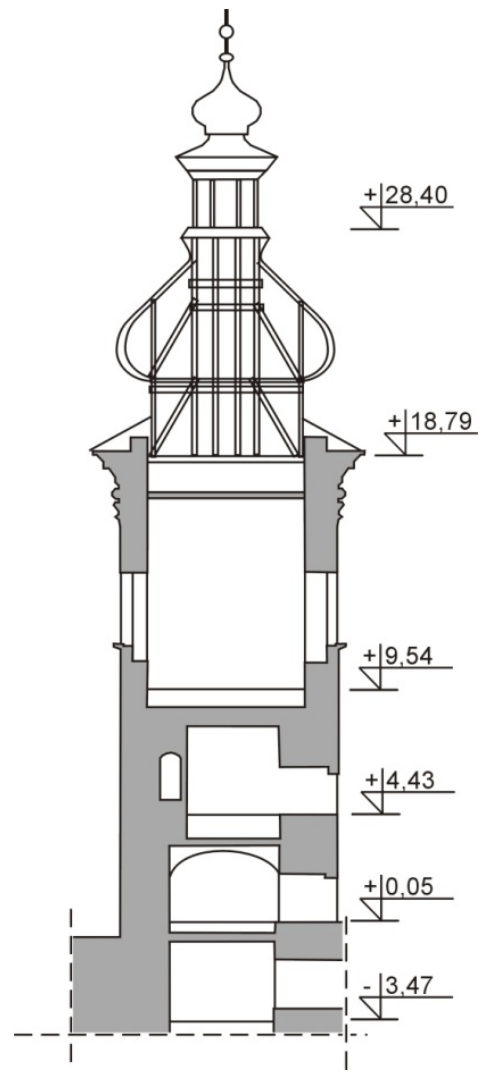

Fig. 2. General diagram of the tower Rys. 2 Ogólny przekrój wieży 
There are three bells in the belfry, Urban, Jan and Maryan, supported by steel yokes and truss structure, (Fig. 3). They were casted in 1639 by Szczepan Meutel and Jerzy Olivier. Urban is considered as one of the largest historical bells in Poland. Larger are only The Royal Sigismund Bell in the Sigismund Tower of the Wawel Cathedral in the Kraków and Tuba Dei bell hanging in the tower of Ss. Johns Cathedral in Torun.
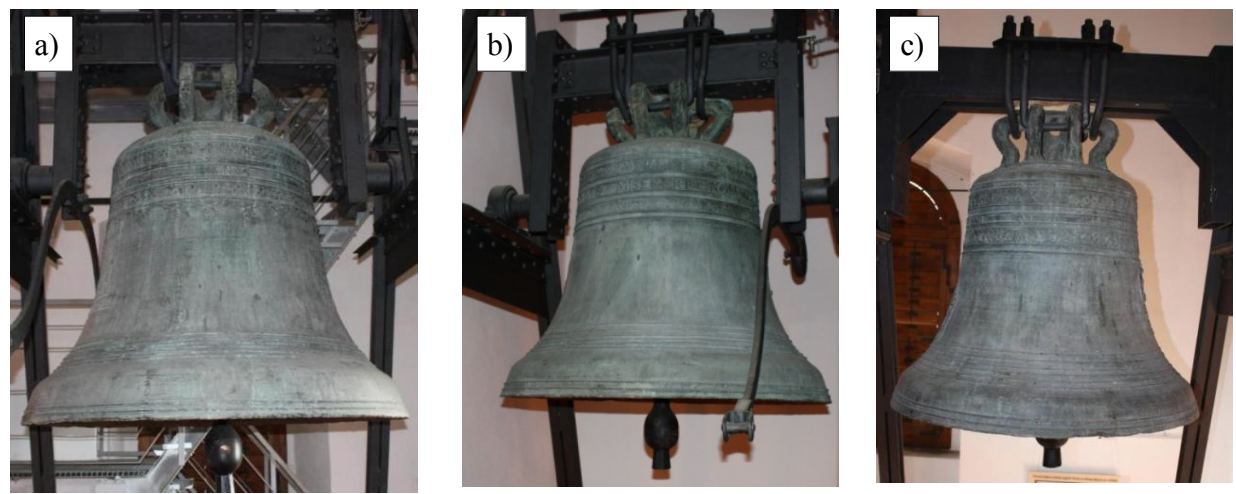

Fig. 3. Bells and their yokes: a) Urban, b) Jan, c) Maryan

Rys. 3. Dzwony i ich jarzma: a) Urban, b) Jan, c) Maryan

\section{The technical condition of a steel structure}

\subsection{Geometric shape of the load-bearing system}

The main load-bearing steel structure, directly supporting the bells in the bell chamber, consists of riveted space truss supported by three steel beams. Structure is dated from 1928. The original design documentation and static calculations are missing. So, for identification of their geometrical arrangement, visual inspection was used with appropriate measuring equipment. General view of recognized static system is shown in Fig. 4.

Elements of structure are made of hot-rolled UPN sections. Leg members forming the main components of the structure are battened build-up elements, connected through packing plates, but with too long distances between packing plates to check element for buckling as a single integral member. Bracing members are made of single or double UPN sections connected only at the beginning and in the end of element, without intermediate battens. Three steel joist, supporting the whole structure are made of IPN240 sections, and each of them has span equal to $6,3 \mathrm{~m}$.

During the inspection, all steel shapes were checked to find out their type. Some of them were old-fashioned and are not in production today, so their section properties were read from textbooks from the beginning of last century [4], 
[11]. Thickness measurement of the web and flange enabled to assess rolling tolerances and size of potential corrosion losses. The influence of the environment on the structure was determined by assessment of the condition of surface protection.

The state of the structure as a whole was identified as a good, and there were no signs of degradation or damage. Also it was checked that the structure did not show any distortion or excessive vibration of load-bearing system parts during the dynamic action of the bells.
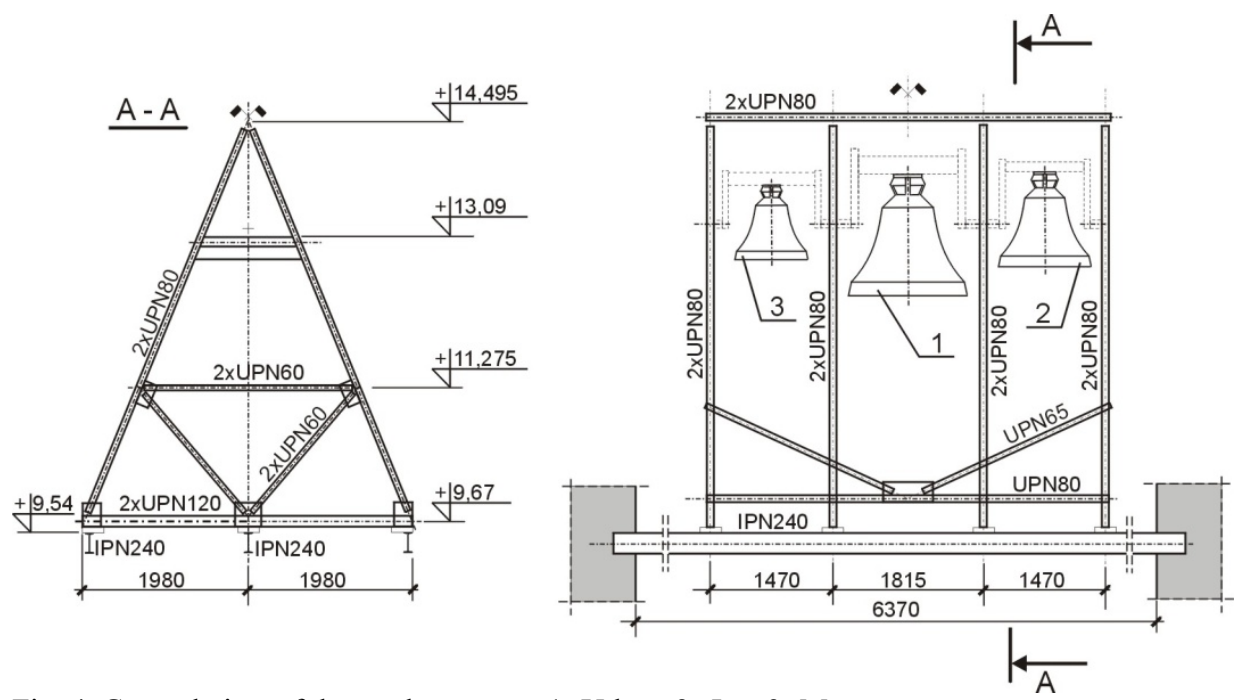

Fig. 4. General view of the steel structure: 1- Urban, 2- Jan, 3- Maryan

Rys. 4. Ogólny widok konstrukcji stalowej: 1 - Urban, 2 - Jan, 3 - Maryan

\subsection{Mechanical properties of steel and connectors}

It was not possible to collect any samples of material to take direct destructive tests, because the structure is now treated as a relic, so non-destructive methods were used to determine the crucial properties of a material. The hardness test of steel and connectors (rivets) was applied and relationship given from literature [6] has enabled to estimate strength parameters:

$$
R_{e}=2,418 \cdot H B ; R_{m}=3,224 \cdot H B ;
$$

where: HB is Brinell hardness.

Although it is considered that the results of hardness measurement for historical steel should be treated with caution, obtained results give insight into real mechanical parameters of steel.

To provide proper measurements, the portable hardness tester (type TH170) was used in case of sections. Measurements were done in three 
areas (flanges of two beams and the gusset plate). There were at least six measurement points in each area. A few rivets were cut-off during the change of the steel yoke few years ago, so testing of the rivets could be performed in laboratory, not in situ.

Obtained results are presented in Table 1 and 2, as mean values from measurements and calculated standard deviation.

Table 1. The mechanical parameters of the steel based on hardness testing

Tabela 1. Mechaniczne parametry stali w oparciu o badania twardości

\begin{tabular}{|l|c|c|}
\hline & $\mathbf{R}_{\mathbf{e}}\left[\mathbf{N} / \mathbf{m m}^{\mathbf{2}}\right]$ & $\mathbf{R}_{\mathbf{m}}\left[\mathbf{N} / \mathbf{m m}^{\mathbf{2}}\right]$ \\
\hline Mean value & 305 & 406 \\
\hline Standard deviation & 20 & 27 \\
\hline
\end{tabular}

Table 2. The mechanical parameters of the rivets based on hardness testing

Tabela 2. Mechaniczne parametry nitów w oparciu o badania twardości

\begin{tabular}{|l|c|c|}
\hline & $\mathbf{R}_{\text {er }}\left[\mathbf{N} / \mathbf{m m}^{2}\right]$ & $\mathbf{R}_{\mathbf{m r}}\left[\mathbf{N} / \mathbf{m m}^{\mathbf{2}}\right]$ \\
\hline Mean value & 318 & 423 \\
\hline Standard deviation & 8 & 11 \\
\hline
\end{tabular}

\subsection{Connections}

The whole structure is riveted, with bolted erection joints. The diameter of rivets, used to connect main elements, is equal to $21 \mathrm{~mm}$. The bolts are not marked and they have diameter $16 \mathrm{~mm}$. All exposed connections were checked on the occurrence of possible cracks. Loosening of bolts and rivets was checked visually by tapping.

\section{Assessment of load-bearing structure}

It was decided, that structural resistance, serviceability and durability of structure would be checked using the present valid standards and regulations (Eurodode 3) [1], [4]. Previous standards and regulations [3], [13] served only as informative background.

\subsection{Actions}

A bell is physical pendulum, i.e. rigid body with a mass, free to rotate about a fixed horizontal axis of rotation [12]. Bell's movement causes periodic horizontal $\mathrm{H}$ and vertical V forces, shown in Fig. 5. In Eurocode family there is no standard giving directly design guidance and actions coming from bell's motion. The forces arising from ringing have been taken from DIN 4178 [5]. 


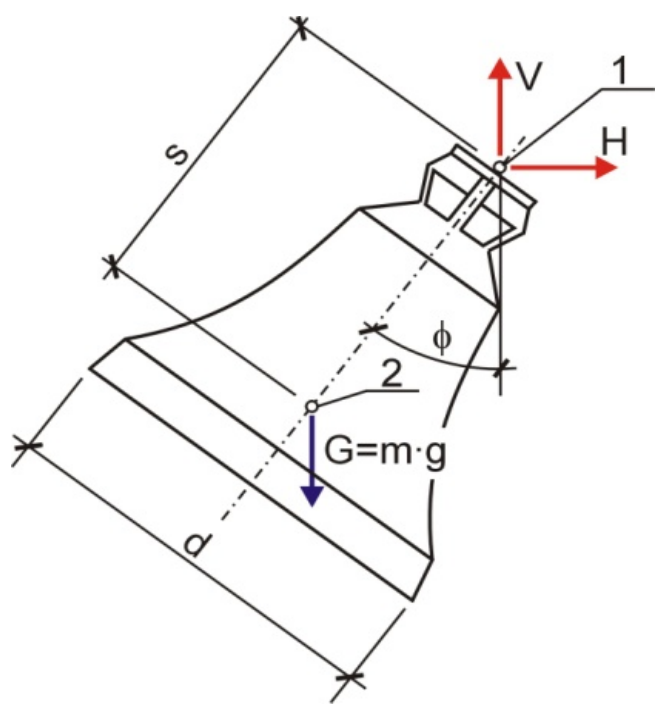

Fig. 5. Vertical and horizontal forces associated with bell movements; 1 - axis of rotation, 2 - centre of gravity, $\mathrm{m}$ - mass of a bell, $\phi$ - angular displacement

Rys. 5.Pionowe i poziome siły związane z ruchem dzwonu; 1 - oś obrotu, 2 - środek ciężkości, $\mathrm{m}$ - masa dzwonu, $\phi$ - przemieszczenie kątowe

The main parameters influencing the forces associated with bell movement are: bell diameter $d_{n}$, weight of bell $G_{n}$, swing angle $\alpha_{n}$ (maximum value of angular displacement $\phi$ ), shape factor $\mathrm{c}_{\mathrm{n}}$ and strike rate N. Such parameters, for bells housed in considered belfry, are shown in Table 3. All bells are suspended by cranked steel yokes.

Table 3. Bells housed in the belfry and their main parameters

Tabela 3. Pomieszczenie dzwonów w dzwonnicy i ich główne parametry

\begin{tabular}{|c|c|c|c|c|c|c|}
\hline No. & Name & $\begin{array}{c}\text { Basic tone, } \\
{[-]}\end{array}$ & $\begin{array}{l}\text { Diameter } \\
\text { of the bell, } d_{n} \\
{[\mathrm{~mm}]}\end{array}$ & $\begin{array}{c}\text { Swing } \\
\text { angle, } \alpha_{n} \\
{\left[{ }^{\circ}\right]}\end{array}$ & $\begin{array}{c}\text { Weight } \\
\text { of bell, } \mathbf{G}_{\mathbf{n}} \\
{[\mathrm{kN}]}\end{array}$ & $\begin{array}{c}\text { Strike } \\
\text { rate, } N \\
{[1 / \mathrm{min}]}\end{array}$ \\
\hline 1 & Urban & cis 1 & 1535 & 64 & 24 & 46 \\
\hline 2 & Jan & e1 & 1200 & 54 & 12 & 50 \\
\hline 3 & Maryan & gis1 & 950 & 56 & 5,8 & 56 \\
\hline
\end{tabular}

Static values of actions coming from excitations were considered as two cases of loading, for each bell. First one was the situation of the maximum horizontal force $H_{n, \max }$ and accompanying value of the vertical force $V_{n}$, second one was the case of the maximum vertical force $V_{n, \max }$ with accompanying value of the vertical force $\mathrm{H}_{\mathrm{n}}=0$. Values of considered actions were calculated using the expressions [5]: 


$$
\begin{aligned}
& H_{n, \max }=c_{n} \cdot G_{n} \cdot \lambda_{\max , h}\left(\alpha_{n}\right) \\
& V_{n}=c_{n} \cdot G_{n} \cdot \lambda_{z u g, v}\left(\alpha_{n}\right)+G_{n} \\
& V_{n, \max }=c_{n} \cdot G_{n} \cdot \lambda_{\max , v}\left(\alpha_{n}\right)+G_{n}
\end{aligned}
$$

where: $\lambda_{\max , \mathrm{h}}, \lambda_{\max , v}, \lambda_{\text {zug,v }}$ are coefficients describing the ratio of the dynamic force amplitude to the weight of the bell, and

$c_{n}$ is shape factor, giving the ratio of $s$ length (distance from center of gravity to axis of rotation, see Fig. 5) to the effective length of simple gravity pendulum with the same period of the motion, as considered bell.

Values of horizontal and vertical forces obtained from equations $(2) \div(4)$ and examined cases of loading are shown in Table 4.

Table 4. Horizontal and vertical forces coming from bells (characteristic values)

Tabela 4. Poziome i pionowe siły wywołane ruchem dzwonów (wartości charakterystyczne)

\begin{tabular}{|c|c|c|c|}
\hline No. & Name & Case 1 of loading & Case 2 of loading \\
\hline 1 & Urban & $\mathrm{V}_{1}=26,5 \mathrm{kN} ; \mathrm{H}_{1, \max }=15,1 \mathrm{kN}$ & $\mathrm{V}_{1, \max }=42,5 \mathrm{kN} ; \mathrm{H}_{1}=0$ \\
\hline 2 & Jan & $\mathrm{V}_{2}=12,4 \mathrm{kN} ; \mathrm{H}_{2, \max }=6,1 \mathrm{kN}$ & $\mathrm{V}_{2, \max }=18,5 \mathrm{kN} ; \mathrm{H}_{2}=0$ \\
\hline 3 & Maryan & $\mathrm{V}_{3}=6,0 \mathrm{kN} ; \mathrm{H}_{3, \max }=3,0 \mathrm{kN}$ & $\mathrm{V}_{3, \max }=9,0 \mathrm{kN} ; \mathrm{H}_{3}=0$ \\
\hline
\end{tabular}

Forces coming from ringing were considered as leading, but also thermal actions were taken into account. Chamber with bells has a large openings, only partially closed by sound shutters, so the temperature changes of structural elements are the same as changes of shade air temperature. Initial temperature when structural element is restrained was considered as $\mathrm{T}_{0}=8^{\circ} \mathrm{C}$, maximum shade air temperature was designated as $\mathrm{T}_{\max }=36^{\circ} \mathrm{C}$ and minimum shade air temperature $\mathrm{T}_{\min }=-30^{\circ} \mathrm{C}$.

\subsection{Static analysis}

Structural analysis was made using Autodesk Robot Structural Analysis software. Model was built as a space frame, as shown in Fig. 6 . The behaviour of the connections was considered in analysis as fully rigid or simple.

Buckling analysis was performed to determine the effects of deformed geometry on the structure. Obtained global mode of instability is shown in Fig. 7, with elastic critical buckling load factor $\alpha_{\mathrm{cr}}=10,8$. 


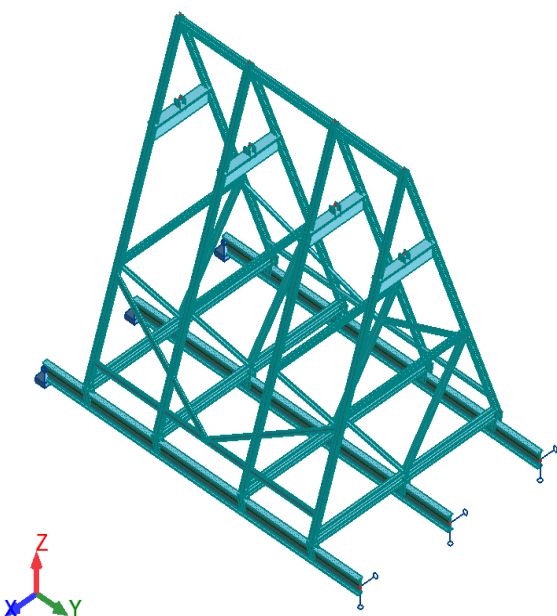

Fig. 6. Frame modeling with the finite element approach

Rys. 6 Model ramy w ujęciu MES

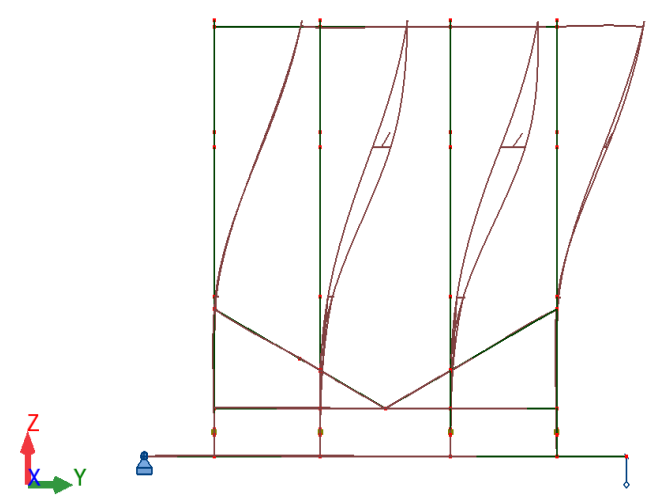

Fig. 7. Mode of global instability of structure

Rys. 7 Forma globalnej niestateczności konstrukcji

Although $\alpha_{\mathrm{cr}}=10,8>10$, it was decided to perform second order analysis, with influence of global initial sway imperfections. Initial imperfection (global sway of structure) was assessed as $\phi=3,6 \cdot 10^{-3} \mathrm{rad}$. The internal forces and moments were determined using elastic global analysis. Partial factors for gravity and imposed loads were taken as specified in [8] $\left(\gamma_{G}=1,35\right.$ and $\left.\gamma_{Q}=1,50\right)$. According to [5], load arrangement of horizontal and vertical forces coming from bells was considered as a sum of all forces produced by each bell.

Based on the hardness testing the mechanical parameters of steel were assumed as for steel grade S235. Cross sections resistance and member stability were checked using the procedures taken from [9]. All criteria were satisfied, although the utilization degree of elements capacity was rather high.

\subsection{Dynamic analysis}

Fundamental frequency of steel supporting structures, obtained from FE model, is equal to $\mathrm{f}_{\mathrm{s}}=1,54 \mathrm{~Hz}$. A strike rate of bells lies in the range between 46 and 56 impacts per minute (see Table 3), so the swing rate becomes $\mathrm{n}=23 \div 28$ swings $/ \mathrm{min}$. This results in the swing frequency $\mathrm{f}=23 / 60 \div 28 / 60=$ $=0,38 \div 0,46 \mathrm{~Hz}$. So, the forces associated with bells have frequency over three times less than fundamental frequency of steel structures.

According to simple design rules [2] resonance with the harmonic components of the bell forces - particularly that of the third harmonic - should be avoided. Such criterion is fulfilled when fundamental structure frequency 
is at least $20 \%$ higher than the excitation frequency of the third harmonic. In considered case:

$$
3 \cdot f \cdot 1,2=3 \cdot(0,38 \div 0,46) \cdot 1,2=1,37 \div 1,66 \mathrm{~Hz} \approx f_{s}=1,54 \mathrm{~Hz}
$$

So above criteria is nearly fulfilled, and it was assumed that resonance did not occur. More sophisticated dynamic analysis and measurements of existing structure (supporting steel structure and the tower) are now in progress.

\subsection{Fatigue analysis}

For fatigue verifications the provisions of EN 1993-1-9 [10] and [7] were applied.

In the past, up to 2012, only one bell (Maryan) was ringing three times a day. Only once a week two bells (Maryan and Jan) were launched and three times a year all three bells were used. Now, from 2012 the system of ringing is quite similar, but Jan tolls every day, instead of Maryan. To verify failure caused by fatigue, as a representative value of actions forces coming from one bell was considered. Effective time of ringing was measured as 3 times a day $\mathrm{x} 4 \mathrm{~min}$, so taking into account strike rate (see Table 2) it gives about 300 numbers of cycles per day. So in period 1928-2012 total number of cycles associated with Maryan swinging is equal to $\mathrm{N}_{3}=10,3 \cdot 10^{6}$, and number of cycles associated with Jan ringing (from 2012 up now) is equal $\mathrm{N}_{3}=0,1 \cdot 10^{6}$.

Nominal stresses were calculated at the site of potential fatigue initiation, coming from characteristic values of actions. It was find out, that the greatest impact of fatigue occurs in longitudinal beams made of IPN240. Up to 2012 the beam was not welded, so detail category was assumed as $\Delta \sigma_{\mathrm{c}}=90$ (structural element with holes subject to bending and axial force). In 2012, during the modernization work, upper part of structure was joined to the beam by welding, so detail category has changed to $\Delta \sigma_{\mathrm{c}}=80$. It was verified that under fatigue loading criterion (5) is fulfilled:

$$
\frac{\gamma_{F f} \cdot \Delta \sigma_{E, 2}}{\Delta \sigma_{C} / \gamma_{M f}} \leq 1,0
$$

where $\gamma_{\mathrm{Ff}}$ and $\gamma_{\mathrm{Mf}}$ are partial factors and $\Delta \sigma_{\mathrm{E}, 2}$ is equivalent constant amplitude stress range at $2 \cdot 10^{6}$ cycles.

The fatigue analysis also showed the elements, that can be particularly careful observed during the future inspections. 


\section{Conclusions}

The building of bell tower is one of the most recognizable landmarks in the city. Now stands as relic and currently is popular tourist attraction. Recently, the interior of the belfry became publicly available. Now chambers of belfry are also used as a gallery.

According to the safety reason, the supporting steel structure was analyzed to assess its strength and durability. The paper presents some specific problems associated with assessing the resistance of old steel structure, loaded in non typical way.

\section{Bibliography}

[1] Agocs Z., Ziółko J., Vičan J., Brodniansky J.: Assessment and refurbishment of steel structures. Spon Press, Taylor \& Francis Group, Ister Science Ltd., 2005.

[2] Bachmann H. et al.: Vibration problems in structures. Practical guidelines. Birkhauser Verlag, 1995.

[3] Bryła S.: Podręcznik budownictwa żelaznego. Nakładem Księgarni Polskiej Bernarda Połonieckiego, 1924.

[4] Czapliński K.: Dawne wyroby ze stopów żelaza. Dolnośląskie Wydawnictwo Edukacyjne, Wrocław, 2009.

[5] DIN 4178 Glockentürme. Deutsches Institut für Normung, 2005.

[6] Gosowski B., Organek P.: Use of the hardness test in-situ for evaluation of strength of steel from the early 20th century. Metal Structures - Scientific Technical Conference, Kielce-Suchedniów, 2-4 July 2014, pp.139-142.

[7] Kühn B. et al.: Assessment of existing steel structures: Recommendations for estimation of remaining fatigue life. European Commission Joint Research Centre, 2008.

[8] PN-EN 1990 Eurocode - Basis of structural design. PKN, Warszawa 2004.

[9] PN-EN 1993-1-1 Eurocode 3: Design of steel structures - Part 1-1: General rules and rules for buildings. PKN, Warszawa 2006.

[10] PN-EN 1993-1-9 Eurocode 3: Design of steel structures - Part 1-9: Fatigue. PKN, Warszawa 2007.

[11] Pszenicki A.: Tablice momentów statycznych i bezwładności blach i kątowników używanych w mostownictwie i budownictwie stalowem. Komitet Wydawniczy Podręczników Akademickich przy Ministerstwie W.R i O.P., Warszawa 1932.

[12] Rapp P.: Historical bells - mechanics and drive problems. Journal of Heritage Conservation, No. 40/2014, pp. 41-57.

[13] Rozporządzenie Ministra Robót Publicznych z dnia 18 czerwca 1929 r. zawierające przepisy o granicach wytrzymałości materiałów i konstrukcyj budowlanych. 


\section{ANALIZA NOŚNOŚCI I TRWAŁOŚCI STALOWEJ KONSTRUKCJI WSPORCZEJ NA WIEŻY DZWONNICY KOŚCIOŁA ŚW. TRÓJCY W KROŚNIE}

\section{Streszczenie}

Artykuł opisuje analizę konstrukcji stalowej, podtrzymującej trzy dzwony w dzwonnicy Kościoła Św. Trójcy w Krośnie. Konstrukcja jest datowana na 1928 rok i ma formę przestrzennej kratownicy nitowanej o smukłych elementach. Masa całkowita wszystkich dzwonów, pochodzących z XVII wieku, równa się niemal 4200 kilogramów, więc siły dynamiczne pochodzące od kołysania się ich są całkiem duże. W artykule przedstawiono pewne problemy związane z oszacowaniem nośności starych konstrukcji stalowych, traktowanych jako zabytkowe. Analiza objęła oszacowanie technicznego stanu konstrukcji, ocena oddziaływań i wpływów środowiskowych, określenie mechanicznych parametrów stali elementów i nitów metodami nieniszczącymi, a także analizę statyczną i dynamiczną konstrukcji. Ze względu na wieloletnia eksploatacje konstrukcji, przeprowadzono również weryfikację zmęczeniową używając metody naprężeń nominalnych zwanej metodą klasyfikacyjną.

Słowa kluczowe: wieża dzwonnicy, analiza statyczna, analiza dynamiczna, zmęczenie

Przestano do redakcji:26.05.2015

Przyjęto do druku:10.01.2016

DOI: $10.7862 / \mathrm{rb} .2015 .205$ 